\title{
Library Management Mode in the Era of Internet +
}

\author{
Xinghui Gao \\ Xi'an Aeronautical Polytechnic Institute. China \\ meetingexpert@sina.com
}

Keywords: Internet +; library; management mode.

\begin{abstract}
This At present, the mankind has entered in the era of Internet + and the integration of industries and Internet is an inevitable trend. Library management is no exception. In this context, this paper, first of all, analyzes the main points of library management mode and points out that the library management and reader service is the core of library management mode. Then books management in the era of Internet + is explored, including the digitization and networking of books resources, informatization and automation of book lending and systematization and integration of books management. The followed analysis is given to the reader service in the era of Internet + , including providing targeted services, providing knowledge-based services, providing comprehensive services, etc.
\end{abstract}

\section{Introduction}

As a public cultural institution, the library plays a crucial role in the literature management, knowledge popularization, social education and other fields. Jorge Luis Borges, a famous giant of writer, once said: "if there is heaven, it is the library". With the continuous development of era, especially the wide application of information technology in modern society, great changes have taken place in library management mode. It experiences a development from the traditional manual management to digital management, network management and intelligent management. With the contribution of network information technology, the cultural service of library obtains great development and promotion. Currently, the mankind has entered into the era of Internet + . The socalled Internet + is a new format of Internet development based on web 2.0. Its combination with the traditional industry is the in-depth integration of Internet and the traditional industry by taking advantage of information and communication technologies as well as web platforms, rather than the simple superposition of the two. The library management mode in the era of Internet + is the in-depth integration of library management mode and network information technology, which plays a very important function in the books management and reader service.

\section{Key Points Analysis of Library Management Mode}

Library management mode refers to the totality of management activities, management plans or management strategies which the library adopts under the guidance a specific management concept or management thought. It has very important influence on the final effect of management. As a public institution of cultural service, the most important contents covered in the management mode of library are the books management and reader service. Firstly, in terms of books management, books are the most important resources of a library and also the basis for it to realize its value of providing cultural service. Both the purchase and update of books are the important parts of library management; Secondly, in terms of reader service, providing the public with reading service is the core content of the library, because its essence is a public cultural service institution. Therefore, providing reader service has become the most important work of the library and the quality of reader service has a great influence on the continuation and development of the library. 


\section{Library Management in the Era of Internet +}

\subsection{The Digitization and Networking of Book Resources}

Since China accessed to the Internet in 1994, the network has received rapid development in China. At present, China already has the world's largest number of Internet users and the network has become an indispensable element in the daily life of Chinese people. Digital library has a history more than 20 years since its emergence, and it is the embodiment of the development of network information technology in the field of library. The digitization and networking of book resources is the basic work of digital library. It is also the general requirements of library management mode construction in the era of Internet + . Resources of traditional library are mainly print resources, imposing restrictions of space and time on reading. The resources of digital library and the library in the era of Internet + consist of print resources and digital resources. To realize the digitization and networking of print resources is the premise and foundation for the books management in the era of Internet +.Librarians should accomplish corresponding work by employing type-in, scanning and other technology means.

\subsection{The Informatization and Automation of Book Lending}

The books management of the library mainly includes books purchasing, sorting, lending, renewing, protection and other work items, in which book lending is the most important part of the books management, because book lending is the fundamental way for the library to realize its function of knowledge dissemination and social education. In the past, the management of book lending was achieved by manual recording, with low efficiency and high error rate. And with the adoption of semi-automatic lending based on "scanning code", the time resource is saved and error rate is also greatly reduced. However, it is far from enough to satisfy demands of books management in the era of Internet + , promoting the inevitable development trend of the informatization and automation of book lending. In this regard, the application of RFID system can play a good role, because it can compensate for the defects in the business management. On the basis of simplifying the operation process, it saves the librarians from the heavy and repeated daily work, so that they can engage in the work more important.

\subsection{The Systematization and Integration of Books Management}

The development and evolution of library can be divided into three stages: the first one is the stage of traditional library; the second one is the stage of digital library; the third one is the stage of library in the era of Internet +. The library in different stages keeps great difference in the literature resources, management way and management goal. Of course, the library at each stage is not the simple negation to its previous one, but the development and promotion on the basis of the former. In terms of books management, traditional library mainly adopt the manual offline management while digital library is evolved to online management. For library in the era of Internet + , the books management is equipped with both forms -- online form and offline form, which is more systematic and comprehensive. It can not only achieve the efficient management of book resources, but can also play important role in the deepening and development of reader services.

\section{The Reader Service in The Era of Internet +}

\subsection{Providing Targeted Services According to the Needs of Readers}

The traditional reader service is undifferentiated service. The so-called undifferentiated service refers to that librarians give the homogenous services to all readers, and there is no difference and hierarchy in the content and form of services. This is a usual manifestation of lagging service concept and objective reflection of laggard service technologies. With the continuous development of network information technology, the undifferentiated reader service has lost the touch with objective needs of time development, restricting the better implementation of the library function of reader service. As a result, to provide targeted service in accordance with the need of readers has become the inevitable requirement for the reshape and deepening of library management mode in the era of Internet + . Currently, the continuous development of big data, cloud computing and other technologies lays a solid foundation for the library to provide personalized reader services. The library should take advantage of information technologies, adhere to demands of time and start from the subtle 
psychology of readers, so as to provide highly-targeted reader service with high-density value. The library can set corresponding login credential in the web interface and mobile phone APP, requiring readers to log into the network books management system through the login name and password. The network books management system will record the reader's borrowing history and reading assessment to analyze his/her reading preferences, such as "category of literature and history -- Chinese history - a fan of the history of the Ming and Qing Dynasties". Once related books are updated, the library will send a message to the reader in a timely manner and provide targeted services. The targeted service is not only embodied in its pertinence, but also reflected on the initiative. In the past, the reader service was "readers ask for service". But in the era of Internet + , the reader service is that the library provides readers with services that they may need according to their preference, timely and actively.

\subsection{Providing Knowledge-Based Services Adhering to the Development of Times}

The reader service is the core function of library management and it is also the basic requirement for the library to realize knowledge dissemination and social education. At present, with the continuous development of era and constantly accelerating of social life pace, the connotation and form of the reader service has changed greatly. It is increasingly hard for the traditional reader service to adapt to the practical need of readers. Thus, changes are imminent, in which the transformation from informational service to knowledge-based service is the key point. To the previous reader service, whether it is the manual service or network interface service, what it gives to readers is the informational service. For example, in the manual service, when readers ask about the position of books and borrowing status, the librarian gives the corresponding reply after the access to information. This is a way relatively time-consuming. In the network interface service, readers can input the name of the book they want by themselves, and then the information system will show corresponding information, including the position of the book, the remaining number of the book and the lending status. However, it is far from enough comparing to the actual demands of the readers. The reader service in the era of Internet + takes providing knowledge-based service as the goal and the development of library management mode must be based on this point. The knowledge-based reader service is the integration, refining and deepening of the informational reader service. It has higher value density and better reader service efficiency. The knowledge-based service not only includes the general information of the book, but also covers the evaluation of different borrowers as well as the recommendations of other books of the same kind, which holds the similar style of "douban reading". It has a very profound value in university library and plays a rare role in subject researches of teachers and students. In short, the transformation from the informational reader service to knowledge-based reader service is the basic requirement of the Internet + era.

\subsection{Providing Comprehensive Services Based on Mobile Network}

The birth and popularization of the mobile network has brought great changes to reading habits of people. Especially in recent years, with the popularity of the large-screen Smartphone, IPAD and various intelligent reading tools, the mobile network client has become the main carrier for people to acquire literature resources and perform reading activities. Therefore, in addition to playing the proper role of traditional network, the library reader service in the era of Internet + should rely on the mobile network timely according to the development trend of mobile web, so as to provide comprehensive service for readers. First of all, the library can make good use of related social software, such as WeChat, microblog, and so on. Some mainstream social software like WeChat and mircoblog is the important means for young groups to achieve social interaction and information acquirement. These kinds of social software are widely used in a variety of groups. By 2016, the number of WeChat registered users has reached 927 million and almost all smart phones have downloaded and installed WeChat. The library can open a related WeChat public number. The National Library and other wellknown libraries have opened the corresponding public number to push related information to the readers regularly, so that readers can enjoy more services. In addition, libraries where conditions permit can develop mobile phone APP by themselves and then push service to the readers in the form of APP. Currently, many libraries have their own mobile phone APP. For example, the APP of the Shanghai Library is equipped with multiple service functions, such as book information, 
bibliographic retrieval, branch library navigation, and so on. It plays a nice role in the expansion and extension of reader service in the network era. Compared to the traditional reader service, the reader service based on mobile network can help readers break through the restriction of time and space to carry out reading activities anytime and anywhere, better realizing the library's function of knowledge dissemination and social education.

\section{Conclusion}

For library management, the development of network information technology is not only an opportunity, but also a challenge. The library should start from the general characteristics of Internet + era and construct new library management mode from two perspectives -- books management and reader service.

\section{References}

[1]. Liu Yingchun. On Management Innovation of Library in the Internet Era [J]. Sci-Tech Information Development \& Economy, 2012, 22 (14): 3-5

[2]. Liu Xiaoyan. Library Management in the Internet Age [J]. Chinese Information, 2015 (01): 4447

[3]. Qiu Minghui. Design of Digital Library Based on User Experience -- A Case Study of CNKI Full-text Database of Chinese Doctoral Dissertations [J]. Journal of Intelligence, 2011,30 (07): 162-168

[4]. Shi Yuanfeng. Analysis of Library Management in "Internet +" Era [J]. Comprehensive Digest, 2016 (07): 44-46 